\title{
Unusual variants of non-Langerhans cell histiocytoses
}

\author{
Ruggero Caputo, MD, ${ }^{\mathrm{a}}$ Angelo Valerio Marzano, MD, ${ }^{\mathrm{a}}$ \\ Emanuela Passoni, MD, ${ }^{a}$ and Emilio Berti, MD $^{\mathrm{b}}$ \\ Milan, Italy
}

\begin{abstract}
Histiocytic syndromes represent a large, heterogeneous group of diseases resulting from proliferation of histiocytes. In addition to the classic variants, the subset of non-Langerhans cell histiocytoses comprises rare entities that have more recently been described. These last include both forms that affect only the skin or the skin and mucous membranes, and usually show a benign clinical behavior, and forms involving also internal organs, which may follow an aggressive course. The goal of this review is to outline the clinical, histologic, and ultrastructural features and the course, prognosis, and management of these unusual histiocytic syndromes. ( $\mathrm{J}$ Am Acad Dermatol 2007;57:1031-45.)
\end{abstract}

$\mathrm{H}$ istiocytic syndromes represent a large, puzzling group of diseases resulting from proliferation of cells called histiocytes. ${ }^{1}$

The term "histiocyte" includes cells of both the monocyte-macrophage series and the Langerhans cell (LC) series, both antigen-processing and antigen-presenting cells deriving from $\mathrm{CD} 34^{+}$progenitor cells in the bone marrow.

In 1987 , the Histiocyte Society proposed a classification of histiocytic syndromes based on 3 classes: (1) class I, corresponding to LC histiocytoses (LCH); (2) class II, encompassing the histiocytoses of mononuclear phagocytes other than LC (non-LCH); and (3) class III, comprising the malignant histiocytoses. ${ }^{2}$ In addition to the classic variants listed in Table I, the group of non-LCH includes unusual or extremely rare disorders that have more recently been described (Table II). Indeed, among the latter, indeterminate cell (IC) histiocytosis (ICH) is a disease in which the predominant cells have the characteristics of both LC and macrophages ${ }^{3}$ and whose actual existence as a separate entity is still debated. ${ }^{4}$ Moreover, this heterogeneous group comprises both

From the Institute of Dermatological Sciences, University of Milan-Fondazione IRCCS Ospedale Maggiore Policlinico, Mangiagalli e Regina Elena ${ }^{\mathrm{a}}$; and Department of Clinical and Preventive Medicine, University of Milano-Bicocca. ${ }^{\mathrm{b}}$

Funding sources: None.

Conflicts of interest: None declared.

Reprint requests: Angelo Valerio Marzano, MD, Institute of Dermatological Sciences, Via Pace 9-20122, Milano, Italy. E-mail: francesca. alessi@unimi.it.

Published online May 10, 2007.

0190-9622/\$32.00

(c) 2007 by the American Academy of Dermatology, Inc.

doi:10.1016/j.jaad.2007.03.014
Abbreviations used:
$\mathrm{BCH}$ : benign cephalic histiocytosis
ECD: Erdheim-Chester disease
GEH: generalized eruptive histiocytosis
HPMH: hereditary progressive mucinous
IC: indeterminate cell
ICH: indeterminate cell histiocytosis
JXG: juvenile xanthogranuloma
LC: Langerhans cell
LCH: Langerhans cell histiocytoses
MR: multicentric reticulohistiocytosis
PNH: progressive nodular histiocytosis
PX: papular xanthoma
SBH: $\quad$ sea-blue histiocyte
SBHS: sea-blue histiocytic syndrome
XD: $\quad$ xanthoma disseminatum

forms affecting only the skin or the skin and mucous membranes, such as hereditary progressive mucinous histiocytosis (HPMH) and progressive nodular histiocytosis (PNH), and forms involving also internal organs, such as Erdheim-Chester disease (ECD) and sea-blue histiocytic (SBH) syndrome (SBHS). The former usually have a benign clinical behavior, whereas the latter may follow a progressive course.

Thus, the purpose of this review is to schematically outline the clinical, histologic, and ultrastructural findings and the course, prognosis and management of these uncommon histiocytic syndromes on the basis of both our personal experience and an accurate review of the literature. The clinical characteristics, course, and management of these unusual variants of non-LCH are summarized in Table III, whereas their histopathologic, immunohistochemical, and ultrastructural features are indicated in Table IV. Markers and antibodies used for immunohistochemistry are listed in Table V. 
Table I. Classic forms of non-Langerhans cell histiocytosis, abbreviations used

\author{
$\mathrm{GEH}$, generalized eruptive histiocytosis \\ $\mathrm{BCH}$, benign cephalic histiocytosis \\ JXG, juvenile xanthogranuloma \\ PX, papular xanthoma \\ $X D$, xanthoma disseminatum \\ NX, necrobiotic xanthogranuloma \\ SHML, sinus histiocytosis with massive lymphadenopathy \\ MR, multicentric reticulohistiocytosis
}

\section{INDETERMINATE CELL HISTIOCYTOSIS Definition}

In 1985, Wood et $\mathrm{al}^{5}$ first described as ICH an unusual, distinctive variant of cutaneous histiocytosis whose cardinal features, distinguishing it from LCH, were: (1) lack, on ultrastructural study, of Birbeck granules; (2) absence, on histology, of epidermotropism; and (3) lack of extracutaneous involvement.

Furthermore, advances in the immunophenotypic characterization of histiocytic dendritic cells and macrophages subsequently led to the demonstration that the IC expressed both LC and monocyte/macrophage markers, ie, S-100/CD1 and CD68/CD14, respectively. ${ }^{6}$ Various hypotheses have been proposed on the origin of IC, ie, whether IC are immature precursors of LC, LC are precursors of IC, or both are independent types of dendritic cells. ${ }^{7}$

\section{Age of onset and incidence}

ICH affects predominantly adults, showing no sex- or age-specific predilection, although about one third of the cases so far reported in the literature are pediatric. ${ }^{4,8-15}$

Since the original description of Wood et al, ${ }^{5}$ only about 20 cases of ICH had been reported, until a recent study on a large collection that included 18 patients with ICH. ${ }^{4}$

\section{Clinical findings}

Two clinical subtypes seem to predominate: a solitary nodular form ${ }^{11-14,16}$ (Fig 1, $A$ ) and a multiple papulonodular form ${ }^{3,5,6,8-10,15,17-26}$ (Fig 1, B). The former is usually characterized by a single, soft red asymptomatic nodule about $1 \mathrm{~cm}$ in diameter; the latter presents with a widespread eruption of multiple, firm asymptomatic lesions ranging in size from a few millimeters to $1 \mathrm{~cm}$, varying in color from dark red to brownish and covered by intact skin.

The multiple nodular form has also been documented as part of nodular scabies, a persistent reaction after acute scabies infestation, possibly representing a prolonged response of IC and
Table II. Unusual variants of non-Langerhans cell histiocytosis, abbreviations used

$\mathrm{ICH}$, indeterminate cell histiocytosis

$\mathrm{PNH}$, progressive nodular histiocytosis

$\mathrm{HPMH}$, hereditary progressive mucinous histiocytosis

ECD, Erdheim-Chester disease

SBHS, sea-blue histiocytic syndrome

lymphocytes to mite antigens. ${ }^{27,28}$ On the other hand, the development of generalized eruptive ICH at the site of already healed pityriasis rosea has also been described, further suggesting that ICH may occur as a lymphohistiocytic reaction to various antigens. ${ }^{9}$ However, in our view, such cases should be regarded as distinct from classic ICH.

Mucous membranes are always spared. Usually, there is no visceral involvement and the patients are in good general health.

\section{Laboratory findings}

Routine laboratory tests and radiographic investigations usually show nonabnormalities.

\section{Histopathologic, immunohistochemical, and ultrastructural findings}

Light-microscopic evaluation reveals an infiltration of histiocytic cells in the whole dermis and sometimes within the epidermis. The proliferating cells show an abundant, pale eosinophilic cytoplasm and large, irregularly folded or twisted nuclei. A few mitotic figures and multinucleated giant cells may be observed. Clusters of lymphocytes are admixed (Fig 2).

Immunohistochemically, the proliferating cells are $\mathrm{KP} 1(\mathrm{CD} 68)^{+}, \mathrm{S}-100^{+}, \mathrm{CD}^{+} \mathrm{a}^{+}$, and factor $\mathrm{XIIIa}^{-5,16,18,20,24}$ In summary, these cells display similar histologic and antigenic features to LC. Ultrastructurally, however, they differ in that Birbeck granules are absent. ${ }^{12,18,20,24}$

\section{Course and prognosis}

Based on a review of the literature that includes the recent report by Ratzinger et $\mathrm{al}^{4}{ }^{4} 15$ patients presenting with solitary lesions and showing a benign clinical course exist ${ }^{11-14,16}$; among these, two patients presented at birth with a solitary nodule that spontaneously regressed ${ }^{12}$ or was removed by shave excision ${ }^{13}$ without relapse, respectively.

On the other hand, 24 cases with widespread cutaneous lesions have been described, 3,5,6,8-10,15,17-26 the majority of which having an indolent or selflimited course; indeed, in a number of reported cases treatment and follow-up were not stated. $3,6,8,18,20,21$ 
Table III. Cutaneous findings, associated abnormalities, course, and treatment of unusual variants of non-Langerhans cell histiocytosis

\begin{tabular}{|c|c|c|c|c|c|}
\hline & ICH & PNH & НРМН & ECD & SBHS \\
\hline Age/sex & $\begin{array}{l}\text { Adults }> \\
\text { children }\end{array}$ & $\begin{array}{c}\text { Children }> \\
\text { adults }\end{array}$ & $\begin{array}{l}\text { Heredity; } \\
\text { beginning in } \\
\text { adolescence } \\
\text { or childhood; } \\
\text { mainly women }\end{array}$ & $\begin{array}{l}\text { Middle-aged and } \\
\text { older adults }\end{array}$ & $\begin{array}{l}\text { Sometimes familial; } \\
\text { beginning in } \\
\text { adolescents or } \\
\text { young adults }\end{array}$ \\
\hline Type of lesion & $\begin{array}{l}\text { Dark-red to } \\
\text { brownish } \\
\text { papules or } \\
\text { nodules }\end{array}$ & $\begin{array}{l}\text { Yellow-brown or } \\
\text { yellow-pink } \\
\text { papules or } \\
\text { nodules }\end{array}$ & $\begin{array}{l}\text { Skin-colored, } \\
\text { red, or yellowish } \\
\text { papules or } \\
\text { nodules }\end{array}$ & $\begin{array}{l}\text { Red-brown } \\
\text { papules merg- } \\
\text { ing into } \\
\text { plaques; } \\
\text { the lesions may } \\
\text { become slack } \\
\text { and atrophic }\end{array}$ & $\begin{array}{l}\text { Nodules and waxy } \\
\text { plaques; macular } \\
\text { brownish } \\
\text { hyperpigmentation }\end{array}$ \\
\hline Pattern & $\begin{array}{l}\text { Solitary } \\
\text { nodular form; } \\
\text { multiple pap- } \\
\text { ulonodular } \\
\text { form }\end{array}$ & $\begin{array}{l}\text { Generalized, } \\
\text { with random } \\
\text { distribution }\end{array}$ & $\begin{array}{l}\text { Multiple lesions; } \\
\text { symmetric } \\
\text { distribution }\end{array}$ & $\begin{array}{l}\text { Multiple lesions; } \\
\text { symmetric } \\
\text { distribution }\end{array}$ & Multiple lesions \\
\hline Localization & $\begin{array}{l}\text { No } \\
\text { preferentially } \\
\text { involved sites }\end{array}$ & $\begin{array}{l}\text { Sometimes, } \\
\text { prominent facial } \\
\text { involvement }\end{array}$ & $\begin{array}{l}\text { Face, hands, } \\
\text { forearms, legs }\end{array}$ & $\begin{array}{l}\text { Eyelids, axillae, } \\
\text { groin, neck, } \\
\text { trunk, face }\end{array}$ & $\begin{array}{l}\text { Prominent facial } \\
\text { involvement; trunk, } \\
\text { hands, feet }\end{array}$ \\
\hline $\begin{array}{l}\text { Mucous } \\
\text { membrane } \\
\text { involvement }\end{array}$ & No & $\begin{array}{l}\text { Yes (oral, laryngeal, } \\
\text { conjunctival) }\end{array}$ & No & $\begin{array}{l}\text { Yes (laryngeal, } \\
\text { oral, } \\
\text { conjunctival) }\end{array}$ & No \\
\hline $\begin{array}{l}\text { Systemic } \\
\text { symptoms/ } \\
\text { involvements }\end{array}$ & $\begin{array}{l}\text { Usually none; } \\
\text { possible } \\
\text { association } \\
\text { with } \\
\text { hematologic } \\
\text { disorders }\end{array}$ & $\begin{array}{l}\text { Usually none; } \\
\text { few reports of } \\
\text { association with } \\
\text { various } \\
\text { systemic } \\
\text { disorders }\end{array}$ & None & $\begin{array}{l}\text { Fever, weakness, } \\
\text { weight loss/ } \\
\text { bone (patchy } \\
\text { osteosclerosis), } \\
\text { neurological, } \\
\text { and pulmonary } \\
\text { involvement; } \\
\text { diabetes } \\
\text { insipidus }\end{array}$ & $\begin{array}{l}\text { Liver, spleen, } \\
\text { bone marrow, } \\
\text { lung, lymph node, } \\
\text { retinal or nervous } \\
\text { involvement }\end{array}$ \\
\hline Clinical course & $\begin{array}{l}\text { Usually benign; } \\
\text { in few cases, } \\
\text { evolution in } \\
\text { hematologic } \\
\text { disorders, } \\
\text { notably } \\
\text { leukemia }\end{array}$ & $\begin{array}{l}\text { Progressive course } \\
\text { of the skin } \\
\text { lesions without } \\
\text { spontaneous } \\
\text { involution, but } \\
\text { benign clinical } \\
\text { behavior }\end{array}$ & $\begin{array}{l}\text { Slowly spreading } \\
\text { to other regions } \\
\text { of the body; } \\
\text { slowly increas- } \\
\text { ing number of } \\
\text { the lesions; no } \\
\text { spontaneous } \\
\text { resolution }\end{array}$ & $\begin{array}{l}\text { Usually } \\
\text { progressive, } \\
\text { with a high } \\
\text { mortality }\end{array}$ & $\begin{array}{l}\text { Usually benign } \\
\text { for the idiopathic } \\
\text { form; related to } \\
\text { that of the primary } \\
\text { disorder for } \\
\text { secondary } \\
\text { forms }\end{array}$ \\
\hline Management & $\begin{array}{l}\text { Usually none; } \\
\text { in few cases, } \\
\text { various che- } \\
\text { motherapy } \\
\text { regimens }\end{array}$ & $\begin{array}{l}\text { Intralesional and } \\
\text { systemic cortico- } \\
\text { steroids; cyclo- } \\
\text { phosphamide-all } \\
\text { with unsatisfac- } \\
\text { tory response; } \\
\text { surgery }\end{array}$ & $\begin{array}{l}\text { Usually none; } \\
\text { in few cases, } \\
\text { surgery }\end{array}$ & $\begin{array}{l}\text { Systemic } \\
\text { corticosteroids; } \\
\text { radiation; vari- } \\
\text { ous chemother- } \\
\text { apy regimens; } \\
\text { surgery-all usu- } \\
\text { ally with poor } \\
\text { response }\end{array}$ & None \\
\hline
\end{tabular}

$E C D$, Erdheim-Chester disease; $H P M H$, hereditary progressive mucinous histiocytosis; $I C H$, indeterminate cell histiocytosis; $P N H$, progressive nodular histiocytosis; SBHS, sea-blue histiocytic syndrome.

Three cases with fatal outcome have, however, been described: one adult patient who died of mast cell leukemia, ${ }^{24}$ another one with non-Hodgkin's lymphoma converted to ICH who developed terminal acute monocytic leukemia, ${ }^{25}$ and an infant with a malignant histiocytic nonleukemic behavior. ${ }^{15}$ A case of systemic ICH with ocular involvement, treated with polychemotherapy and corneal 
Table IV. Laboratory investigations, histopathologic, immunohistochemical, and ultrastructural findings of unusual variants of non-Langerhans cell histiocytosis

\begin{tabular}{|c|c|c|c|c|c|}
\hline & ICH & PNH & HPMH & ECD & SBHS \\
\hline $\begin{array}{l}\text { Laboratory } \\
\text { findings }\end{array}$ & NS & $\begin{array}{l}\text { NS (notably, } \\
\text { normal lipid } \\
\text { metabolism }\end{array}$ & $\begin{array}{l}\text { NS (notably, } \\
\text { normal lipid } \\
\text { metabolism }\end{array}$ & $\uparrow \mathrm{ESR} ; \uparrow \mathrm{ALP}$ & $\begin{array}{l}\text { Leukopenia; } \\
\text { thrombocytope- } \\
\text { nia; } \\
\text { anemia }\end{array}$ \\
\hline Histopathology & $\begin{array}{l}\text { Dermal } \\
\text { infiltration } \\
\text { of HC with eosino- } \\
\text { philic cytoplasm } \\
\text { and folded nuclei; } \\
\text { presence of multi- } \\
\text { nucleated giant } \\
\text { cells and } \\
\text { lymphocytes }\end{array}$ & $\begin{array}{l}\text { Dermal } \\
\text { infiltration of } \\
\text { HC with vacuo- } \\
\text { lated clear } \\
\text { cytoplasm; } \\
\text { presence of } \\
\text { Touton-like } \\
\text { giant cells and } \\
\text { aspects of } \\
\text { "collagen } \\
\text { trapping" }\end{array}$ & $\begin{array}{l}\text { Dermal nodular } \\
\text { aggregates of } \\
\text { epithelioid or } \\
\text { spindle- } \\
\text { shaped HC; } \\
\text { deposition of } \\
\text { mucinous } \\
\text { material }\end{array}$ & $\begin{array}{l}\text { Dermal } \\
\text { infiltration of } \\
\text { foamy HC; } \\
\text { presence of } \\
\text { Touton giant } \\
\text { cells }\end{array}$ & $\begin{array}{l}\text { Dermal } \\
\text { micronodular } \\
\text { infiltrate of } \mathrm{HC} \\
\text { containing } \\
\text { granules staining } \\
\text { blue-green with } \\
\text { Giemsa }\end{array}$ \\
\hline $\begin{array}{l}\text { Immuno- } \\
\text { histochemistry }\end{array}$ & $\begin{array}{l}\mathrm{KP} 1(\mathrm{CD} 68)^{+++} \\
\mathrm{S}-100^{++}, \mathrm{CD}^{\prime} \mathrm{a}^{+} \\
\text {factor } \mathrm{XIII}^{-}\end{array}$ & $\begin{array}{l}\mathrm{KP} 1(\mathrm{CD} 68)^{+++}, \\
\text {factor XIIla }{ }^{++}, \\
\mathrm{CD}^{+} \mathrm{a}^{-}, \mathrm{S}-100^{-}\end{array}$ & $\begin{array}{l}\mathrm{KP} 1(\mathrm{CD} 68)^{+++}, \\
\text {factor } \\
\mathrm{XIII}^{+++}, \\
\mathrm{CD}^{+} \mathrm{a}^{-}, \mathrm{S}-100^{-}\end{array}$ & $\begin{array}{l}\mathrm{KP} 1(\mathrm{CD} 68)^{+++}, \\
\text {factor } \\
\mathrm{XIIla}^{++} \\
\mathrm{CD}^{+} \mathrm{a}^{-} \\
\mathrm{S}-100^{-}\end{array}$ & $\begin{array}{l}\mathrm{KP} 1(\mathrm{CD} 68)^{+++} \\
\quad \mathrm{S}-100^{-}\end{array}$ \\
\hline $\begin{array}{l}\text { Electron } \\
\quad \text { microscopy }\end{array}$ & $\begin{array}{l}\text { LC-like HC } \\
\text { but lacking } \\
\text { BG }\end{array}$ & $\begin{array}{l}\text { HC with } \\
\text { indented } \\
\text { nucleus and } \\
\text { cytoplasm rich } \\
\text { in ER, Golgi C, } \\
\text { mitoch, lys, } \\
\text { comma-shaped } \\
\text { bodies }\end{array}$ & $\begin{array}{l}\text { HC with } \\
\text { bizarre-shaped } \\
\text { nucleus and } \\
\text { cytoplasm rich } \\
\text { in myelin and } \\
\text { zebra bodies }\end{array}$ & $\begin{array}{l}\text { HC with } \\
\text { cytoplasm } \\
\text { filled with } \\
\text { lipid vacu- } \\
\text { oles, choles- } \\
\text { terol crystals, } \\
\text { myeloid } \\
\text { bodies, lys, } \\
\text { phagos }\end{array}$ & $\begin{array}{l}\text { Granules present } \\
\text { as round dense } \\
\text { bodies, and } \\
\text { rodlike bodies }\end{array}$ \\
\hline
\end{tabular}

$A L P$, Alkaline phosphatase; $B G$, Birbeck granules; $C$, complexes; $E C D$, Erdheim-Chester disease; $E R$, endoplasmic reticulum; $E S R$, erythrocyte sedimentation rate; $H C$, histiocytic cells; $H P M H$, hereditary progressive mucinous histiocytosis; $I C H$, indeterminate cell histiocytosis; LC, Langerhans cell; lys, lysosomes; mitoch, mitochondria; NS, not significant; phagos, phagosomes; PNH, progressive nodular histiocytosis; SBHS, sea-blue histiocytic syndrome.

Table V. Panel of antibodies used

\begin{tabular}{|c|c|c|c|}
\hline Marker & Dilution & Source & Main reactivity \\
\hline S-100 protein* & $1: 400$ & $\begin{array}{l}\text { Novocastra Laboratories Ltd, } \\
\text { United Kingdom }\end{array}$ & $\begin{array}{l}\text { Dendritic cells, including Langerhans cells, nerves, } \\
\text { and melanocytes }\end{array}$ \\
\hline CD1a & Ready to use & DAKO, Cytomation, Denmark & Dendritic cells, including Langerhans cells \\
\hline KP1(CD68) & $1: 50$ & DAKO, Cytomation, Denmark & Monocytes and macrophages \\
\hline Factor XIIIa* & $1: 400$ & DAKO, Cytomation, Denmark & Dermal dendrocytes, monocytes, and macrophages \\
\hline
\end{tabular}

A standard alkaline phosphatase anti-alkaline phosphatase complex method has been used for immunohistochemical studies.

*Polyclonal, others monoclonal.

transplantation, has recently been observed but a long-lasting follow-up was lacking. ${ }^{26}$ In addition to the cases mentioned above, chemotherapy regimens, including vinblastine and 2-chlorodeoxyadenosine, respectively, were necessary in two other cases with extensive and disfiguring cutaneous disease despite the absence of visceral involvement. , $17,22^{2}$

We observed two adult male patients with ICH having widespread cutaneous eruptions without evidence of systemic disease at onset. ${ }^{29}$ In these patients, oral cyclophosphamide gave a good clinical response. However, during a 6- and a 4-year followup period, respectively, several recurrences occurred. These were characterized by more resistant cutaneous manifestations, and required repeated cycles with different intravenous antineoplastic regimens, including first etoposide and subsequently a combination of vinblastine and metylprednisolone. During the 

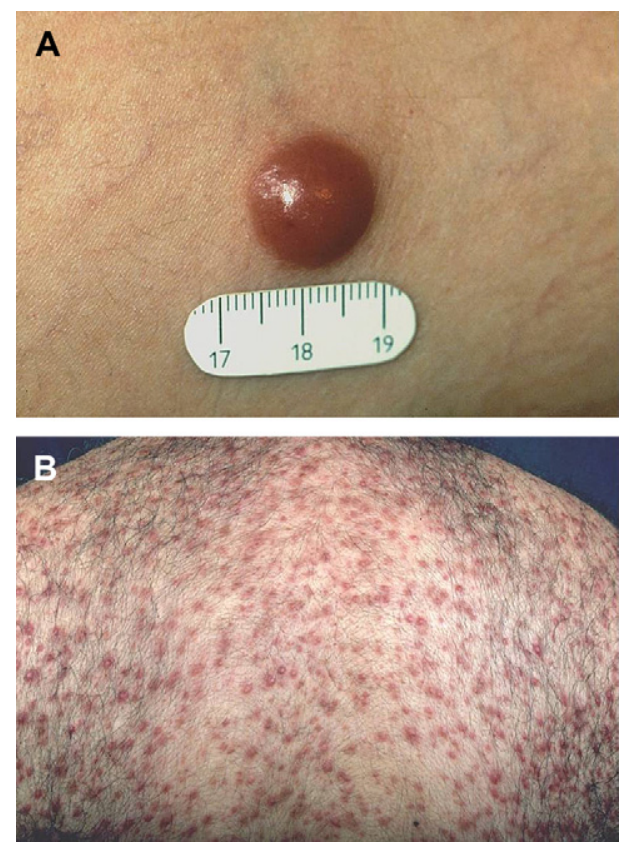

Fig 1. Indeterminate cell histiocytosis. Solitary nodular (A) and multiple papulonodular (B) forms.

last relapse, the first patient responded favorably to a course of treatment with 2-chlorodeoxyadenosine, after the above chemotherapeutic regimens had failed to induce a satisfactory clinical remission. ${ }^{29}$ The other one developed acute myelogenous leukemia 5 years after ICH onset and died during high-dose chemotherapy, consisting of cytosinearabinoside plus idarubicin (unpublished data). Thus, based on our experience, it seems suitable to reconsider the prognosis of $\mathrm{ICH}$, its clinical course being not always so benign as thought in the past, and to strictly monitor the possible onset of an aggressive hematologic disorder.

\section{Differential diagnosis}

The cutaneous lesions observed in ICH are not characteristic. Solitary lesions are very similar to those observed in congenital self-healing reticulohistiocytosis of Hashimoto-Pritzker and in juvenile xanthogranuloma (JXG), and multiple lesions may look like those present in generalized eruptive histiocytosis (GEH) or in multicentric reticulohistiocytosis (MR). ${ }^{30} \mathrm{~A}$ definite diagnosis of ICH is based on the histologic, immunohistochemical, and ultrastructural features of the cells constituting the infiltrate.

\section{Management}

As mentioned above, in the majority of cases the condition does not need any treatment, because its course is usually benign. However, several cases,

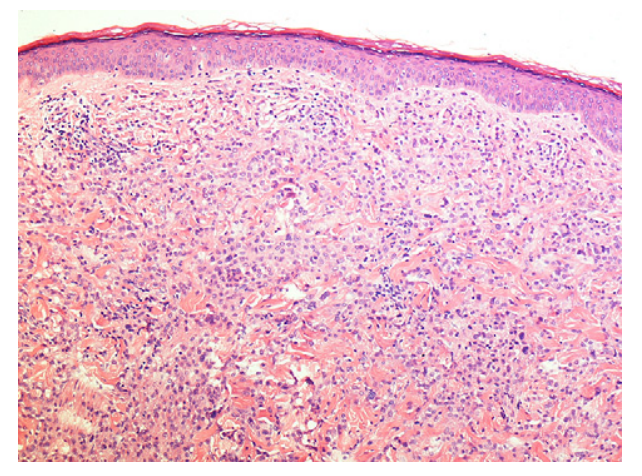

Fig 2. Indeterminate cell histiocytosis. Histology showing dermal infiltration of histiocytic cells, with scattered lymphocytes. (Hematoxylin-eosin stain; original magnification: $\times 100$.)

including our two, ${ }^{9}$ required chemotherapy regimens. $5,15,17,22,24-26$

\section{Comment}

Sidoroff et $\mathrm{al}^{3}$ stated that, clinically, the multiple papulonodular form of ICH is indistinguishable from GEH, a rare non-LCH characterized by an indolent, usually self-healing clinical course. As a consequence, they speculated that GEH seems to be an early, indeterminate stage of various non-LC histiocytic syndromes, most notably including $\mathrm{ICH}$, benign cephalic histiocytosis (BCH), JXG, PNH, xanthoma disseminatum (XD), and MR.

This view on non-LCH has recently been overemphasized by some of the above authors, who proposed that the prototype of this group is xanthogranuloma, all other non-LCH being only variants on xanthogranuloma. ${ }^{4}$ Based on this unifying concept, ICH is regarded as representing various macrophage disorders identified at various time points in the inflammatory response. On the contrary, we defend the view on ICH as a separate entity; however, we suggest lumping it into a clinicopathologic spectrum where $\mathrm{GEH}, \mathrm{BCH}$, and JXG are the benign counterpart, whereas $\mathrm{PNH}, \mathrm{XD}$, and $\mathrm{MR}$ represent more aggressive forms or forms that can be associated with extracutaneous involvement.

\section{PROGRESSIVE NODULAR HISTIOCYTOSIS Definition}

$\mathrm{PNH}$ is a normolipemic non-LCH affecting the skin and mucous membranes with no signs of spontaneous regression of the lesions. "Progressive nodular histiocytosis" is the name suggested in 1985 by one of us ${ }^{30}$ to encompass several cases reported in the literature with similar clinical and histopathologic features, ${ }^{31-34}$ including the first one described as "progressive nodular histiocytoma" by Taunton 

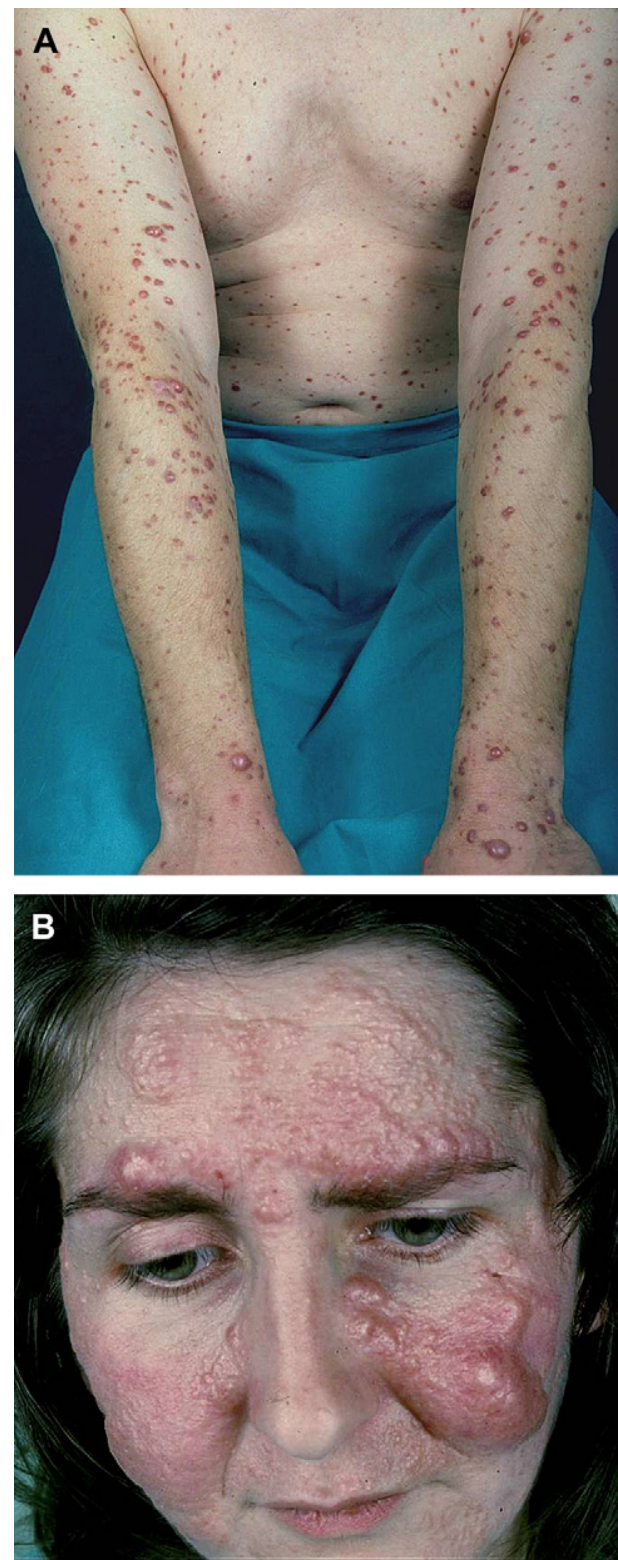

Fig 3. Progressive nodular histiocytosis. A, Multiple papulonodular lesions over upper extremities and trunk. B, Leonine appearance for coalescing of lesions on face.

et $\mathrm{al}^{35}$ in 1978. Up until now, very few universally accepted reports of PNH existed, and these have received diverse nomenclature. ${ }^{31-43}$

\section{Clinical findings}

Clinically, the disease is characterized by the progressive appearance of hundreds of lesions of two different types, namely superficial papules and deep nodules ${ }^{31-43}$ (Fig 3, $A$ ).

The most common lesions are yellow-brown or yellow-pink papules varying in size from 2 to $10 \mathrm{~mm}$, widely and randomly distributed on the body, the flexural areas being spared. These lesions may be present in the oral, laryngeal, and conjunctival mucosae. The second type of lesion is a large dermal nodule, with overlying telangiectasia, which gives it a red-brown color. The nodules range in size from 10 to $50 \mathrm{~mm}$ and are more common on the trunk. Several large nodules over pressure points may show necrosis.

Neither type of lesion is prominent around the joints, but both are often seen around the genitalia. ${ }^{34}$ Sometimes, there is a tendency for lesions to coalesce on the face, producing intense ectropion and a leonine appearance ${ }^{30,32,36,38}$ (Fig 3, B).

Café au lait spots and arthritis are absent.

\section{Laboratory findings}

Laboratory findings, including cholesterol and triglyceride levels and lipoprotein values, are generally within normal limits.

\section{Histopathologic, immunohistochemical, and ultrastructural findings}

Histology shows a dermal infiltrate composed of histiocytes with abundant, vacuolated clear cytoplasm and a variable number of multinucleated, notably Touton-like, giant cells (Fig 4). Among these histiocytes, many lymphocytes and some plasma cells are observed. In some areas, a storiform pattern is seen and an appearance of "collagen trapping" as a result of splaying of collagen bundles is prominent at the infiltrate edge. In biopsy specimens taken from an older lesion, fibrosis is evident and Touton-like giant cells are nearly absent. ${ }^{34,35}$

Immunohistochemically, infiltrating histiocytes are strongly positive for CD68 and factor XIIIa but negative for CD1a and S-100. However, lack of factor XIIIa expression has also been found. ${ }^{37}$

Under the electron microscope, the histiocytes have a large indented nucleus and a scanty cytoplasm. The latter is rich in endoplasmic reticulum, Golgi complexes, and mitochondria, but also contains numerous membrane-bound, electron-dense lysosomes. In addition, there are irregularly shaped, electron-dense granules, some with a comma shape and others with a central electronlucent area. Rare lipid droplets are also seen. Birbeck granules are typically absent. One of us ${ }^{33}$ observed intracytoplasmic granules having a unique and highly complex ultrastructure in a patient with papular histiocytosis closely resembling PNH. They had a wall consisting of two parallel unit membranes separated by a light space of approximately $150 \mathrm{~A}^{\circ}$ and a portion formed as a result of the enlargement of the space between the two unit membranes and containing vesicles. However, these structures have not been found in PNH by other investigators. ${ }^{34,37}$ 


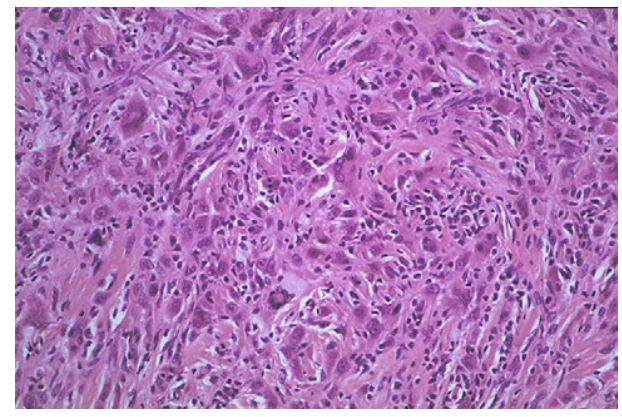

Fig 4. Progressive nodular histiocytosis. Histology revealing dermal infiltrate of histiocytes with abundant, vacuolated clear cytoplasm and several multinucleated, notably Touton-like, giant cells. (Hematoxylin-eosin stain; original magnification: $\times 400$.)

\section{Course and prognosis}

Despite the progressive and deforming nature of the lesions with no signs of spontaneous involution, patients remain in good general health. Spontaneous regression of lesions has only occasionally been reported. ${ }^{31,33,36} \mathrm{PNH}$ has been reported in association with systemic disorders in two patients only: one $^{38}$ had chronic myeloid leukemia, hypothyroidism, and purine and lipoprotein metabolic changes, the other ${ }^{42}$ was a child with precocious puberty, growth hormone deficiency, and a hypothalamic tumor.

\section{Differential diagnosis}

As stated above, PNH may be included within a clinicopathologic spectrum also comprising several entities from which PNH should be distinguished. The histologic and immunohistochemical findings in $\mathrm{PNH}$ are similar to those in JXG, GEH, and BCH. However, in typical JXG, one or several papules and nodules of 0.5 to $1.0 \mathrm{~cm}$ in diameter are present at birth or appear during the first 6 months of life and almost always undergo spontaneous resolution by 2 or 3 years of age. JXG can occur in adults, but also in adults the lesions regress spontaneously. Also in $\mathrm{GEH}$, the lesions, which appear rapidly, usually clear spontaneously leaving brown macules or normalappearing skin. Giant cells are not seen on histology. $\mathrm{BCH}$ can be excluded by the distribution of lesions, early onset, and lack of Touton giant cells. XD, where lesions occur in flexures and tend to coalesce, and where respiratory involvement is common, can also be excluded on clinical grounds. In MR, there is involvement of the hands and mucosal and visceral lesions and destructive arthritis. Papular xanthoma (PX) involves the skin and occasionally the mucosa. It generally resolves spontaneously after a few years. ${ }^{30}$ Histologically, the lesions consist mainly of foamy cells, with essentially no nonlipidized histiocytes. Many intracytoplasmic lipid droplets are seen on electron microscopy. HPMH is an inherited disease. Typically, the lesions are smaller and histologic studies demonstrate the presence of mucin. Lepromatous leprosy may be ruled out because of the absence of intracellular bacilli. Finally, lipogranulomatosis of Farber is an inborn error of lipid metabolism with deposition of free ceramide and ganglioside in the brain, liver, lymph nodes, kidneys, and lungs. The disease, marked by onset in early infancy, usually follows a rapidly progressive course with lipid-laden histiocytic granulomas that involve the skin and mucous membranes. Large papules become confluent into deep nodules on the mucous membranes and around joints. ${ }^{44,45}$

\section{Management}

Treatments, including intralesional ${ }^{34}$ and systemic $^{36}$ corticosteroids and cyclophosphamide, were unable to modify the progressive course of the disease. Surgical procedures were performed to remove enlarging lesions from the membrane mucous sites or the largest nodules of the face, with no evidence of recurrence. ${ }^{32,34,35}$ Carbon-dioxide laser produced cosmetically acceptable results in one patient, ${ }^{37}$ whereas it was followed by recurrence of the lesions over the scar tissue in another one. ${ }^{38}$

\section{Comment}

In our view, PNH may be considered the last stage of particular forms of other non-LCH such as GEH, $\mathrm{PX}, \mathrm{XD}$, and $\mathrm{MR}$, according to the concept of clinicopathologic spectrum mentioned above.

\section{HEREDITARY PROGRESSIVE MUCINOUS HISTIOCYTOSIS Definition}

HPMH was first described in 1988 by Bork and Hoede $^{46}$ as a new non-LCH resembling PNH in its clinical course, but differing from it by several clinical and histopathologic characteristics, notably an autosomal-dominant inheritance and mucinous degeneration.

\section{Age of onset and incidence}

The disease is very rare and affects almost exclusively women; only 11 patients from 6 different families, ${ }^{46-51}$ in addition to two sporadic cases, ${ }^{52,53}$ have been reported. Indeed, we observed a male patient and his daughter both affected by HPMH (unpublished data). In HPMH, the cutaneous manifestations begin in adolescence or childhood.

\section{Clinical findings}

The skin lesions consist of a few to numerous skin-colored to red-brown, pinhead to pea-sized 


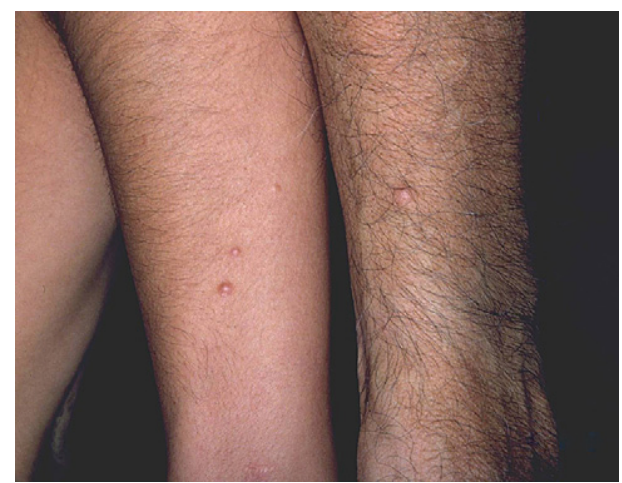

Fig 5. Hereditary progressive mucinous histiocytosis. Skin-colored to red-brown, dome-shaped nodules on forearms of father and daughter.

papules and dome-shaped nodules with a predilection to localize on the face, hands, forearms, and legs (Fig 5). The distribution is symmetric. There are no overlying telangiectases. The lesions do not tend to ulcerate or to merge into plaques. The mucous membranes are always spared. No visceral involvement has been reported.

\section{Laboratory findings}

General investigations do not show any pathologic changes. Results of extensive laboratory examinations reveal normal findings; particularly, there are no abnormalities in lipid metabolism.

\section{Histopathologic, immunohistochemical, and ultrastructural findings}

Histologically, the lesions consist of nodular aggregates of tightly packed epithelioid or spindleshaped histiocytes with large nuclei and abundant cytoplasm in the papillary and mid dermis (Fig 6). Neither involvement of the epidermis nor inflammatory cells are seen, but a relatively high number of mast cells has been observed by some authors. ${ }^{47}$ Moderate to extensive dermal deposition of mucinous material is demonstrated in long-standing tumors. Staining with toluidine blue reveals a marked metachromasia of the histiocytic cells. In accordance with some authors, ${ }^{53}$ immunohistochemical studies performed by us showed positive labeling of the histiocytic cells with KP1 (CD68), and factor XIIIa, but S-100 protein and CD1a were negative. In contrast, other investigators ${ }^{50}$ found that the histiocytes were negative for both KP1 (CD68) and factor XIII.

Ultrastructurally, the histiocytes have large, convoluted, often bizarre-shaped nuclei and one or two prominent nucleoli; the abundant cytoplasm contains numerous myelin bodies and zebra bodies, suggesting lysosomal storage phenomena, and an

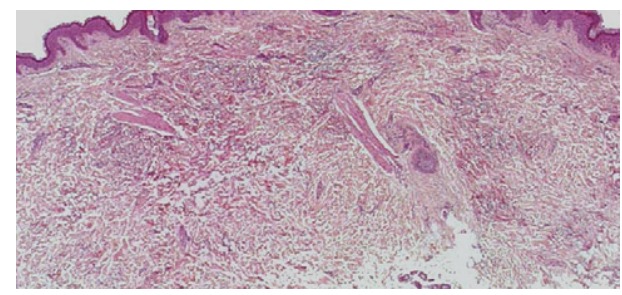

Fig 6. Hereditary progressive mucinous histiocytosis. Histologic pattern consisting of aggregates of tightly packed histiocytes in whole dermis. (Hematoxylin-eosin stain; original magnification: $\times 25$.)

enlarged and dilated rough endoplasmatic reticulum. Typical pleomorphic granules, as described by one of $\mathrm{us}^{33}$ wormlike bodies, or Birbeck granules are absent. ${ }^{46-53}$

\section{Course and prognosis}

The disease shows a progressive course marked by a slowly increasing number of lesions, slowly spreading to other regions of the body and with no spontaneous regression; however, there is no evidence of extracutaneous illness, the general health remaining good with age.

\section{Differential diagnosis}

The main differential diagnoses of HPMH include the majority of non-LCH in addition to some nonhistiocytic disorders. In PNH, lesional cells may lipidize, contain pleomorphic inclusion bodies, and do not produce mucin.

GEH can be differentiated by onset late in life, tendency of the lesions to resolve spontaneously, predominance of epithelioid histiocytes in the lesions, and lack of mucin production. HPMH differs from MR in nearly all clinical aspects, especially the localization of cutaneous nodules and clinical course; moreover, there are no associated articular symptoms, and, histologically, the typical groundglass appearance of the histiocytes is not observed. Among nonhistiocytic disorders, acral persistent papular mucinosis differs from HPMH in that it is not hereditary, children are not affected, and the lesions show mucinous degeneration with a scant histiocytic infiltrate. ${ }^{54}$

Multiple dermatofibromas are larger clinically, and multiple lesions are uncommon over the upper limbs or hands, but inheritance and mucin production in HPMH are essential diagnostic features.

\section{Management}

Considering its benign clinical behavior, most of the patients with this disease received no therapy ${ }^{46,47,51}$; in two cases, some of the tumors were surgically 
removed for cosmetic reasons. ${ }^{47,53}$ Indeed, in several reports the treatments were not stated. ${ }^{49,50,52}$

\section{Comment}

The nature of the disease is poorly elucidated. Its progressive spreading with age, with no tendency to spontaneous regression and its electron microscopy aspects, led to the assumption that HPMH might be a new lysosomal storage disease affecting solely the skin. ${ }^{46,47}$ It has been hypothesized that the stored material was a new phospholipid, eg, a sphingomyelin that could not be detected by the methods available at that time. ${ }^{46,47}$ On the other hand, the same authors stated that a proliferation and accumulation of macrophages as a result of an up to that time unknown stimulus could not be ruled out. Currently, the storage nature of HPMH cannot yet be confirmed.

\section{ERDHEIM-CHESTER DISEASE Definition}

ECD is a rare, multisystem non-LC histiocytoxanthomatosis first described by William Chester ${ }^{55}$ and Jakob Erdheim in 1930.

\section{Age of onset and incidence}

ECD primarily affects middle-aged and older adults. 55 The term "Erdheim-Chester disease" was first coined by Jaffe ${ }^{56}$ in 1972 and, since reporting began in the literature, there have been approximately 180 cases recorded.

\section{Clinical findings}

The disease can involve almost any organ system; thus, the clinical presentation of patients with ECD differs on a case-to-case basis, mostly because of the variety of organ systems that may be involved and the level of disease activity present in each case. Radiographically documentable skeletal involvement is always present and focal bone pain, particularly involving the lower extremities, is the most common presenting symptom in patients with ECD, with an incidence of approximately 50\%. ${ }^{57}$ Indeed, many patients in whom radiographics findings are typical of ECD may be asymptomatic. Pathognomonic radiographic changes in the long bones consist of bilateral and symmetric patchy osteosclerosis involving the metaphysis and diaphysis with epiphysial sparing and loss of a clear definition between cortex and medulla. Distal femur and proximal tibia and fibula are the most frequently affected sites, whereas the disease usually spares the axial skeleton and flat bones. ${ }^{57,58}$ In addition to the sclerotic changes, lytic lesions can be seen in up to 30\% of cases. ${ }^{59}$ Pathologic bone fracture, compression of the femoral neck, and the development of bone abscesses with cutaneous perforation have all been proposed as potential mechanisms involved in the manifestation of bone pain in ECD. ${ }^{57}$ Second in frequency to bone involvement, diabetes insipidus, as a result of hypothalamic/posterior pituitary disease, has been reported in up to one third of patients, often preceding the diagnosis of ECD by several years. ${ }^{57,59}$ Other neurologic involvement is rare but is often the source of significant morbidity. ${ }^{57,59-61}$ It may manifest clinically with cerebellar signs, typically lower extremity ataxia, upper motor neuron deficits, and focal neurologic deficits.

Bilateral painless exophthalmos as a result of retro-orbital histiocytic infiltration is also common, serious cases often progressing to visual impairment. Although retroperitoneal and renal involvement occurs in one third of patients and may manifest clinically as abdominal pain, dysuria, and hydronephrosis, the majority of cases are asymptomatic. ${ }^{57,58}$ Pulmonary involvement is uncommon, occurring in approximately 20\% of reported patients, and is characterized by a progressive course commonly manifesting with dyspnea. ${ }^{62}$ Radiographic changes consist of diffuse interstitial infiltrates and pleural and/or interlobular septal thickening. ${ }^{62-64}$ Although uncommon, lung disease contributes disproportionately to morbidity and mortality associated with ECD, respiratory failure and cardiac failure representing the most common causes of death. ${ }^{57,62}$ The skin involvement is present in one fourth of the cases and consists of xanthomatous lesions clinically identical to those observed in XD or PX. The cutaneous manifestations resembling $\mathrm{XD}$ are papules redbrown in color (Fig 7) at first and then becoming yellowish. These lesions, initially isolated, gradually tend to coalesce and merge into plaques, mostly on the main folds. The hard-elastic texture of the initial lesions tends to slowly diminish with time, and the skin may become slack and atrophic, especially on the folds and face. The distribution of the lesions is typically symmetric and the preferentially involved regions are, in order of frequency, the eyelids, the axillae, the groin, the neck, the trunk, and the face.

Skin manifestations resembling PX are more rare and consist of 2 to $15 \mathrm{~mm}$, rounded, yellow to pinkyellow, asymptomatic papulonodular lesions most frequently involving the back and the head.

\section{Laboratory findings}

Laboratory findings are typically nonspecific and inconsistently include mild elevations of both erythrocyte sedimentation rate and C-reactive protein. An elevation in alkaline phosphatase has been reported in up to $19 \%$ of cases. ${ }^{57}$ 


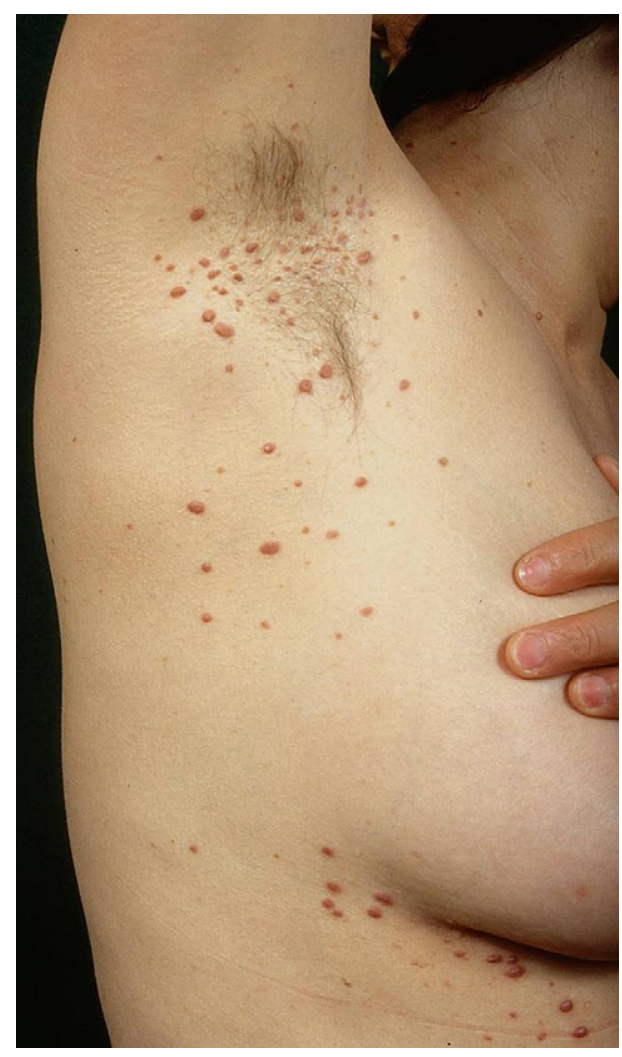

Fig 7. Erdheim-Chester disease. Red-brown papules resembling those of xanthoma disseminatum.

General symptoms of fever, weakness, and weight loss are common.

\section{Histologic, immunohistochemical, and ultrastructural findings}

Histologically, the skin lesions are characterized by a dermal infiltration that is almost entirely composed of foamy histiocytes (Fig 8) in association with small numbers of lymphocytes, plasma cells, and neutrophils. Touton giant cells are constantly present, but vary in number. Immunohistochemically, foamy histiocytes express the following immunophenotype: $\mathrm{KP} 1(\mathrm{CD} 68)^{+}$, factor $\mathrm{XIII}^{+}, \mathrm{CD}^{-}{ }^{-}$, and S- $100^{-}$.

Under the electron microscope, foamy cells are characterized by an abundant cytoplasm completely filled with lipid vacuoles and sometimes containing cholesterol crystals and myeloid bodies. The majority of the histiocytes show the typical features of the macrophages, namely indented nuclei, abundant cytoplasm containing dilated rough endoplasmic reticulum, coated vesicles, and numerous lysosomes and phagosomes. These cells also display slender cytoplasm processes at the periphery. Multinucleated giant cells are produced by aggregation of these

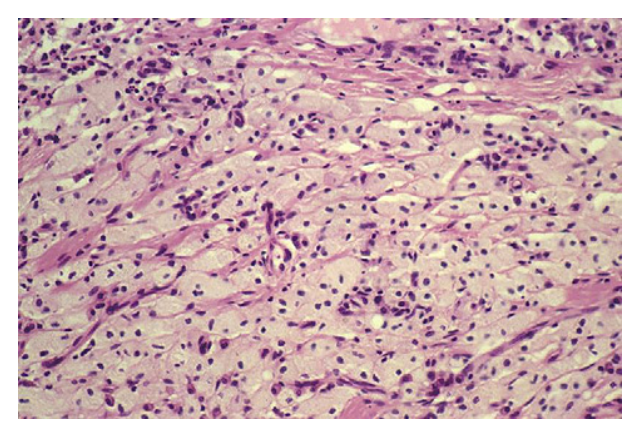

Fig 8. Erdheim-Chester disease. Histologically, skin lesions are characterized by dermal infiltration almost entirely composed of foamy histiocytes. (Hematoxylin-eosin stain; original magnification: $\times 400$.)

macrophages. Birbeck granules are absent and comma-shaped bodies are seen only occasionally.

\section{Course and prognosis}

The course of ECD is usually progressive with a high mortality. The prognosis depends mainly on the extent and distribution of the extracutaneous disease.

In a review of 59 patients, Veyssier-Belot et $\mathrm{al}^{57}$ reported that $22(59 \%)$ of 37 patients with follow-up had died of the disease, $8(36 \%)$ in less than 6 months, the mean survival duration having been just less than 3 years.

\section{Differential diagnosis}

ECD is often misdiagnosed because of its rarity and variety of end-organ involvement. The differential diagnosis is extensive and includes the diseases listed in Table VI. Among the differential diagnoses of particular interest for dermatologists, LCH may be distinguished histologically based on the characteristics of the infiltrate. This includes diagnostic LC with typical convoluted, often reniform, nucleus and abundant, slightly eosinophilic cytoplasm. Immunohistochemically, LC are positive not only for S-100 protein but also for CD1a, whereas, under the electron microscope, they contain Birbeck granules. The absence of well-formed granulomas on histology is helpful in excluding the diagnosis of sarcoidosis. Sinus histiocytosis with massive lymphadenopathy, also referred to as RosaiDorfman disease, ${ }^{65}$ is a rare form of histiocytic proliferation that classically appears in childhood as massive, painless bilateral enlargement of cervical lymph nodes. Affected lymph nodes show a sinusoidal infiltrate of lymphocytes, plasma cells, and characteristic histiocytes with abundant vacuolated cytoplasm; the histiocytes are similar to those seen in $\mathrm{ECD}$, differing mainly in that they frequently contain 
intact lymphocytes within their cytoplasm (ie, emperipolesis). Moreover, in all the 3 disorders mentioned above, bilateral and symmetric osteosclerosis in long bones is lacking.

\section{Management}

Treatment regimens for ECD have included steroids, radiation, chemotherapy, and surgery, although no therapeutic clinical trials have been performed because of the rarity of the disease. Steroids are the most commonly used treatment modality, usually with poor response, although cases of remission of localized disease have been reported. ${ }^{66}$ Radiation therapy has been used to shrink lesions of ECD, the rationale being based largely on its use in a similar disease such as LCH. Chemotherapy, including vinca alkaloids, anthracyclines, and cyclophosphamide, and surgical debulking of tumors have also been used but with discouraging results. ${ }^{57}$ Effectiveness of interferon alfa in ECD has recently been reported. ${ }^{67}$

\section{Comment}

The origin of ECD is unknown. ${ }^{68}$ It is undetermined whether ECD is a monoclonal proliferative disorder or whether it is a polyclonal reactive disease. ${ }^{68,69}$ Although ECD has been known to occur in patients who also have $\mathrm{LCH},{ }^{70}$ the two diseases are generally regarded as representing distinct entities. From a dermatologic perspective, ECD may be considered as a variant of XD with bone and visceral involvement and, thus, having an aggressive clinical behavior.

\section{SEA-BLUE HISTIOCYTIC SYNDROME Definition}

In 1970, Silverstein et $\mathrm{al}^{71}$ coined the term "seablue histiocyte syndrome" to describe a primitive idiopathic storage disease in which many organs were infiltrated by the so-called SBH. SBH are large macrophages whose cytoplasm is filled with granules staining blue or blue-green with Giemsa. Up until now, approximately 60 cases of SBHS have been published. In addition to the primary form of SBHS, it is now clear that there are secondary forms related to a wide variety of conditions, including diseases with a high rate of intramedullary cell death and storage diseases. The common feature is the accumulation of unsaturated lipids within histiocytes as a result of increased production or to a failure of catabolism. The former group includes various blood disorders such as chronic myeloid leukemia, ${ }^{72}$ idiopathic thrombocytopenic purpura, ${ }^{73}$ severe autoimmune neutropenia, ${ }^{74}$ and myelodysplastic syndromes $^{75}$ in which cells are cleared at an increased
Table VI. Differential diagnosis of Erdheim-Chester disease

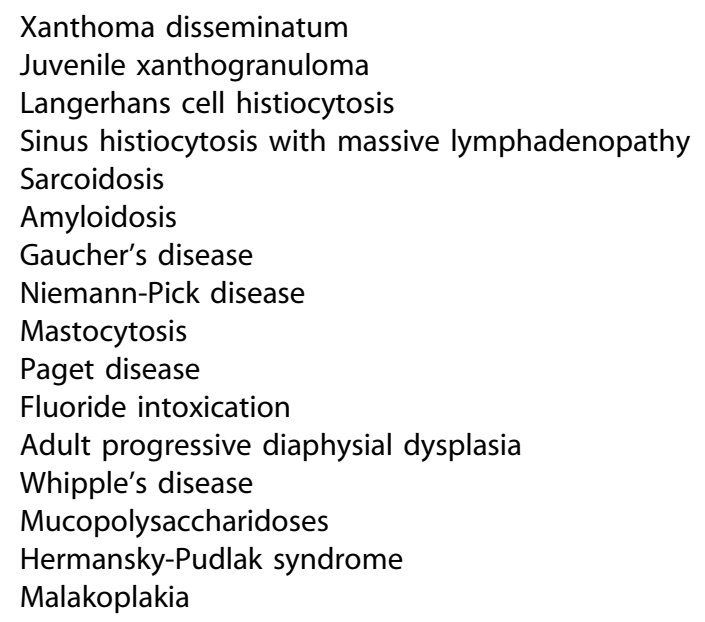

rate by the reticuloendothelial system. The latter group encompasses a variety of inherited metabolic defects including sphingomyelinase deficiency, most notably Niemann-Pick disease. ${ }^{76-78}$ Moreover, longterm parenteral alimentation with fat emulsion ${ }^{79}$ and severe hypertriglyceridemia ${ }^{80}$ have rarely been reported to produce the accumulation of $\mathrm{SBH}$ within the marrow. Finally, SBH have exceptionally been found in the infiltrate of mycosis fungoides. ${ }^{81,82}$

\section{Clinical findings}

In the primary form of SBHS, the most common symptoms are hepatosplenomegaly and bone marrow involvement resulting in hemorrhagic diathesis, then lung infiltrates, lymphadenopathies, and, less frequently, retinal or nervous involvement. ${ }^{83,84}$ Cutaneous changes are very rare, having been observed in a few patients only. ${ }^{85-89}$ They include facial macular brownish hyperpigmentation ${ }^{87}$ and nodular lesions. ${ }^{85,86,88,89}$ Nodular lesions have been observed on the face, trunk, hands, and feet. Eyelid infiltrative swelling and facial waxy plaques are the most prominent cutaneous features, resulting in a puffy appearance $^{86}$ (Fig 9). The disease may be familial. ${ }^{85}$

\section{Histopathologic, immunohistochemic, and ultrastructural findings}

Histologically, cutaneous nodular lesions show an edematous dermis with a sparse micronodular infiltrate composed of large, pale, monomorphous histiocytes containing vacuoles and granules (Fig 10, $A$ ). These granules become clearly visible as inclusion bodies of varying size and shape after staining 


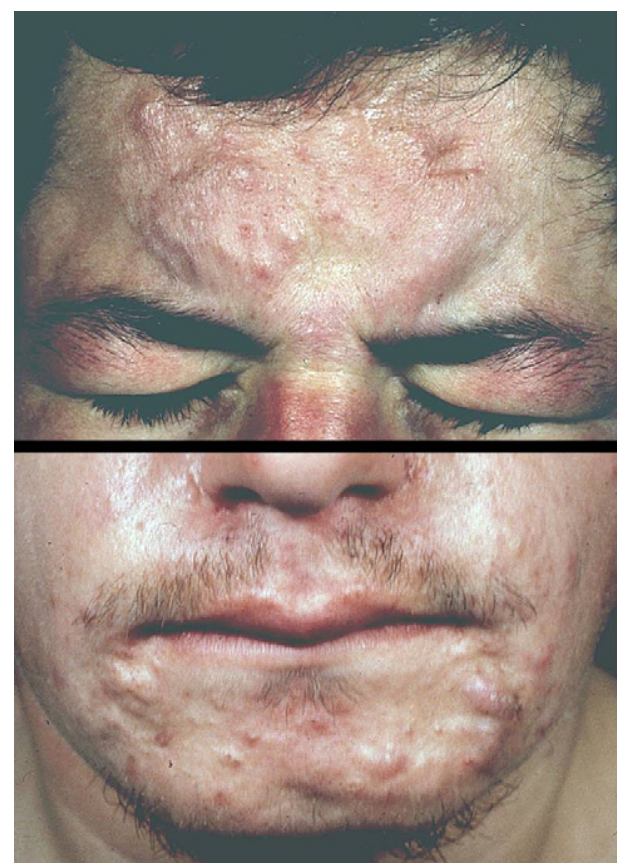

Fig 9. Sea-blue histiocytic syndrome. Facial waxy plaques resulting in puffy appearance. Courtesy of Prof M. Pippione.

with Giemsa (blue-green) (Fig 10, B) and toluidine (dark-blue without metachromasia), and are highly birefringent under polarized light. ${ }^{86}$ Immunohistochemically, the histiocytes are $\mathrm{KP} 1{(\mathrm{CD} 68)^{+}}^{+}$and $\mathrm{S}-100^{-}$; in the literature, they have not been tested for CD1a or for factor XIIIa.

Ultrastructurally, the granules present as round dense bodies, membranous or lamellated structures, occasionally showing a fingerprint appearance, and bodies containing dense rodlike formations. ${ }^{85,86}$ The presence of the rodlike bodies appears to be a striking feature in SBHS, although their significance and origin remain obscure.

\section{Course and prognosis}

The idiopathic form of SBHS pursues a relatively benign clinical course, usually with no progression apart from the skin lesions. In secondary forms, the course is related to that of the primary disorder.

\section{Differential diagnosis}

The main differential diagnoses of primary SBHS include the secondary forms of SBHS. This requires conditions associated with presence of SBH, notably lymphoproliferative disorders and storage diseases, to be ruled out. Because of the puffy appearance of the face observed in primary SBHS, leonine facies as a feature of mycosis fungoides should be excluded, also taking into account that SBH has exceptionally been reported in association with this disease. ${ }^{81,82}$
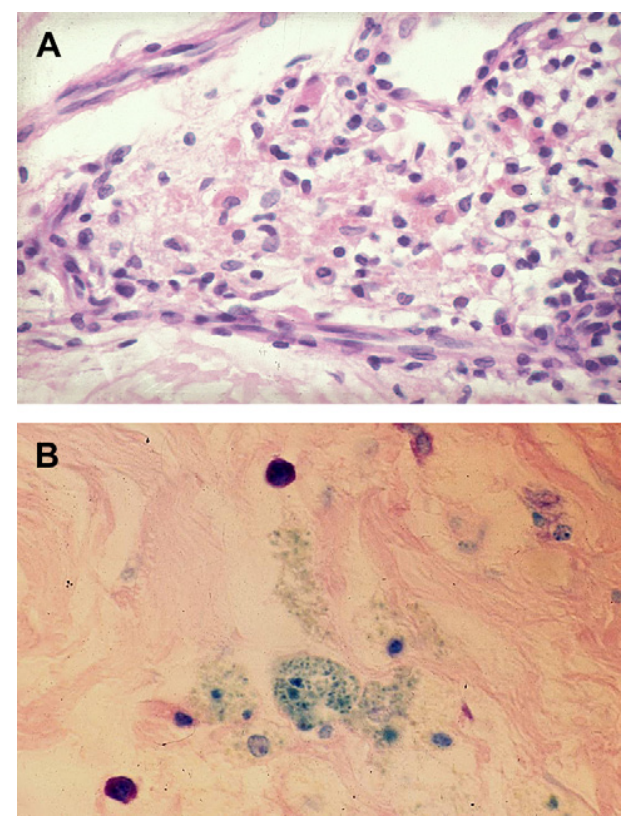

Fig 10. A, Histology of sea-blue histiocytic syndrome. Sparse infiltrate composed of large, monomorphous histiocytes within edematous dermis. (Hematoxylin-eosin stain; original magnification: $\times 200$.) B, Granules within cytoplasm of infiltrating cells appear clearly visible (bluegreen) after staining with Giemsa. (Original magnification: $\times 400$.) Courtesy of Prof M. Pippione.

Moreover, a leonine appearance is sometimes seen in PNH. ${ }^{30,32,36,38}$ Finally, lepromatous leprosy should be considered and ruled out based on the absence of intracellular bacilli.

\section{Management}

No treatment capable of stopping the progression of the cutaneous disease has so far been reported.

\section{Comment}

The pathogenesis of the material stored within $\mathrm{SBH}$ is still unclear, but phospholipids, glycosphingolipids, and ceroids have been identified. Although no consistent enzymatic defect has been identified in these patients, a biochemical derangement in lipid metabolism has been hypothesized. ${ }^{71,90,91}$

Some authors have proposed that a partial sphingomyelinase deficiency is a possible cause of SBHS. ${ }^{92,93}$

\section{CONCLUSIONS}

The clinical, histologic, and ultrastructural findings and the course, prognosis, and management of 5 unusual histiocytic disorders have been reviewed. Although their classification still remains controversial, we suggest lumping all these entities into the wide group of non-LCH. In ICH, the proliferating cells express both macrophage markers, such as KP1 
(CD68), and LC markers, such as S-100 and CD1a. Thus, ICH was proposed to be a separate entity showing an overlap between LCH and non-LCH. We defend the view of ICH as a distinctive entity, but we suggest including it into a spectrum comprising several classic non-LCH on the basis of the strict clinicopathologic and ultrastructural similarities between the latter and ICH.

According to this concept, PNH may be classified into the group of non-LCH, possibly representing the last stage of other non-LCH.

HPMH was proposed to be a storage disease, but this hypothesis cannot yet be confirmed. On the other hand, the dermal deposits of mucin could justify including it in the group of cutaneous mucinoses. However, this form sometimes resembling PNH in its clinical course better fits the diagnostic criteria for non-LCH. ECD could be regarded as a separate entity, distinct from non-LCH because it is a multisystem disorder. Indeed, the fact that the cutaneous manifestations of ECD are usually identical to those of XD makes it conceivable to consider it a form of non-LCH. Finally, the primary form of SBHS is considered to be a primitive idiopathic storage disease, whereas the secondary forms are related to a number of conditions, including diseases with a high rate of intramedullary cell death and storage diseases. Their common feature is the infiltration of many organs by the so-called SBH, making SBHS a true histiocytic syndrome.

\section{REFERENCES}

1. Van Furt R. The nomenclature of mononuclear phagocytic cells: a proposal for a new classification. In: Van Furt R, editor. Mononuclear phagocytes. Oxford: Blackwell; 1970. pp. 1-6.

2. Writing group of the histiocyte society. Histiocytosis syndromes in children. Lancet 1987;1:208-9.

3. Sidoroff A, Zelger B, Steiner $H$, Smith $N$. Indeterminate cell histiocytosis-a clinicopathological entity with features of both X-and non-X histiocytosis. Br J Dermatol 1996;134:525-32.

4. Ratzinger G, Burgdorf WHC, Metze D, Zelger BG, Zelger B. Indeterminate cell histiocytosis: fact or fiction? J Cutan Pathol 2005;32:552-60.

5. Wood GS, Hu CH, Beckstead JH, Turner RR, Winkelmann RK. The indeterminate cell proliferative disorder: report of a case manifesting as an unusual cutaneous histiocytosis. J Dermatol Surg Oncol 1985;11:1111-9.

6. Manente L, Cotellessa C, Schmitt I, Peris K, Torlone G, Muda $\mathrm{AO}$, et al. Indeterminate cell histiocytosis: a rare histiocytic disorder. Am J Dermatopathol 1997;19:276-83.

7. Reifenberger J. The indeterminate cell of the skin. Dermatopathol Pract Concept 1997;3:205.

8. Saijo S, Hara M, Kuramoto Y, Tagami H. Generalized eruptive histiocytoma: a report of a variant case showing the presence of dermal indeterminate cells. J Cutan Pathol 1991;18:134-6.

9. Wollenberg A, Burgdorf WH, Schaller M, Sander C. Longlasting "Christmas tree rash" in an adolescent: isotopic response of indeterminate cell histiocytosis in pityriasis rosea? Acta Derm Venereol 2002;82:288-91.
10. Rodriguez-Jurado R, Vidaurri-de la Cruz $H$, Duràn-Mckinster $C$, Ruì-Maldonado R. Indeterminate cell histiocytosis: clinical and pathologic study in a pediatric patient. Arch Pathol Lab Med 2003;127:748-51.

11. Miracco C, Raffaelli M, de Santi MM, Figiani M, Tosi P. Solitary cutaneous reticulum cell tumor: enzyme-immunohistochemical and electron-microscopic analogies with IDRC sarcoma. Am J Dermatopathol 1988;10:47-53.

12. Levisohn D, Seidel D, Phelps A, Burgdorf W. Solitary congenital indeterminate cell histiocytoma. Arch Dermatol 1993;129:81-5.

13. Jang KA, Ahn SJ, Choi JH, Sung KJ, Moon KC, Koh JK. Histiocytic disorders with spontaneous regression in infancy. Pediatr Dermatol 2000;17:364-8.

14. Amo J, Kawano N, Takasu H, Katsuoka K. A case of solitary indeterminate cell histiocytosis. J Dermatol 2003;30:751-4.

15. Flores-Stadler EM, Gonzales-Crussi F, Greene M, Thangavelu M, Kletzel M, Chou PM. Indeterminate cell histiocytosis: immunophenotypic and cytogenetic findings in an infant. Med Pediatr Oncol 1999;32:250-4.

16. Berti E, Gianotti R, Alessi E. Unusual cutaneous histiocytosis expressing an intermediate immunophenotype between Langerhans' cells and dermal macrophages. Arch Dermatol 1988;124:1250-3.

17. Winkelmann RK, Hu C-H, Kossard S. Response of nodular non-X histiocytosis to vinblastine. Arch Dermatol 1982;118: 913-7.

18. Hui PK, Feller AC, Kaiserling E, Hesse G, Rodermund OE, Haneke $E$, et al. Skin tumor of T accessory cells (interdigitating reticulum cells) with high content of T lymphocytes. Am J Dermatopathol 1987;9:129-37.

19. Weber L, Hesse G, Feller AC, Rodermund O-E. Multizentrischer Hauttumor der interdigitierenden dendritischen Zelle. Hautarzt 1988;39:28-33.

20. Contreras F, Fonseca E, Gamallo C, Burgos E. Multiple selfhealing indeterminate cell lesions of the skin in an adult. Am J Dermatopathol 1990;12:396-401.

21. Grau-Massanés $M$, Millán $F$, Sabater $V$, Jiménez $A$, Frías $F$, Aliaga A. Indeterminate-cell histiocytosis. J Cutan Pathol 1992; 19:526.

22. Daoud MS, Dahl PR, Dicken CH, Phyliky RL. Indeterminate cell histiocytosis treated successfully with 2-chlorodeoxyadenosine. Cutis 1997;59:27-31.

23. Rosenberg AS, Morgan MB. Cutaneous indeterminate cell histiocytosis: a new spindle cell variant resembling dendritic cell sarcoma. J Cutan Pathol 2001;28:531-7.

24. Kolde G, Bröcker EB. Multiple skin tumors of indeterminate cells in an adult. J Am Acad Dermatol 1986;15:591-7.

25. Ségal GH, Mesa MV, Fishleder AJ, Stoler MH, Weich JK, Lichtin AE. Precursor Langerhans cell histiocytosis. Cancer 1992;70:547-53.

26. Calatayud M, Güell JL, Gris O, Puig J, Arrendo E, Huguet P. Ocular involvement in a case of systemic indeterminate cell histiocytosis: a case report. Cornea 2001;20:769-71.

27. Hashimoto K, Fujiwara K, Mehregan A. Current topics of immunohistochemistry as applied to skin tumors. J Dermatol 1993;20:521-32.

28. Hashimoto K, Fujiwara K, Punkwaney J, DiGregorio F, Bostrom P, el-Hoshy L, et al. Post-scabetic nodules: as a lymphohistiocytic reaction rich in indeterminate cells. J Dermatol 2000;27: 181-94.

29. Caputo R, Marzano AV, Passoni E, Bellinvia M. Chemoterapeutic experience in indeterminate cell histiocytosis. Br J Dermatol 2005;153:206-7.

30. Gianotti F, Caputo R. Histiocytic syndromes: a review. J Am Acad Dermatol 1985;13:383-404.

31. Robinson HM, Harmon LE, Firminger HI. Multiple lipoidal histiocytomas with regression. Arch Dermatol 1963;88:660-7. 
32. Rodrìguez H, Saúl A, Galloso de Bello L, Tay J, Peyro E. Nodular cutaneous reactive histiocytosis caused by an unidentified microorganism: report of a case. Int J Dermatol 1974;12:248-60.

33. Caputo R, Crosti C, Cainelli T. A unique cytoplasmic structure in papular histiocytoma. J Invest Dermatol 1977;68:98-104.

34. Burgdorf WHC, Kusch SL, Nix TE, Pitha J. Progressive nodular histiocytoma. Arch Dermatol 1981;117:644-9.

35. Taunton OD, Yeshurun $D$, Jarratt $M$. Progressive nodular histiocytoma. Arch Dermatol 1978;114:1505-8.

36. Torres L, Sánchez JL, Rivera A, Gonzáles A. Progressive nodular histiocytosis. J Am Acad Dermatol 1993;29:278-80.

37. Gibbs NF, O'Grady TC. Progressive eruptive histiocytomas. J Am Acad Dermatol 1996;35:323-5.

38. Ruíz GA, Ruíz AIB, Fraile HA, Martinez IP, Munoz MG. Progressive nodular histiocytosis accompanied by systemic disorders. Br J Dermatol 2000;143:628-31.

39. Iglesias L, Lopez S, Guerra A, et al. Histiocitoma nodular progresivo familiar. Actas Dermo-Sif 1988;79:849-57.

40. Jimenez DL, Alcade $M$, Jimenez MC, et al. Histiocitoma nodular progresivo. Actas Dermo-Sif 1990;81:856-8.

41. Vadoud-Seyedi J, Vadoud-Seyedi R, De Dobbeleer G. Progressive nodular histiocytomas. Br J Dermatol 2000;143:678-9.

42. Beswick SJ, Kirk JM, Bradshaw K, Sanders DSA, Moss C. Progressive nodular histiocytosis in a child with a hypothalamic tumor. Br J Dermatol 2002;146:138-40.

43. Róson E, Flórez A, Feal C, De la Torre C, Garcla-Doval I, Abalde $T$, et al. Progressive nodular histiocytoma associated with thrombocytopenia with absent radii (TAR syndrome) and angiofibromas. Acta Derm Venereol 2006;86:348-50.

44. Farber S, Cohen J, Uzman L. Lipogranulomatosis: a new lipoglycoprotein storage disease. J Mt Sinai Hosp NY 1957; 24:816-37.

45. Moser HW, Prensky AL, Wolfe JH, Rosman NP. Farber's lipogranulomatosis: report of a case and demonstration of an excess of free ceramide and ganglioside. Am J Med 1969;47:869-90.

46. Bork K, Hoede N. Hereditary progressive mucinous histiocytosis in women: report of three members in a family. Arch Dermatol 1988;124:1225-9.

47. Bork K. Hereditary progressive mucinous histiocytosis: immunohistochemical and ultrastructural studies in an additional family. Arch Dermatol 1994;130:1300-4.

48. Iglesias-Diez L, Lopez-Gomes S, Guerra-Tapia A, Martin LG. Familial progressive nodular histiocytoma. Presented at: 17th World Congress of Dermatology; May 24 to 29, 1987; Berlin, Germany.

49. Schroder $K$, Hettmannsperger $U$, Schmuth $M$, Orfanos $C E$, Goerdt S. Hereditary progressive mucinous histiocytosis. J Am Acad Dermatol 1996;35:298-303.

50. Wong D, Killingsworth M, Crosland G, Kossard S. Hereditary progressive mucinous histiocytosis. Br J Dermatol 1999;141: 1101-5.

51. Anthony-Bach N, Pfister R, Grosshans E, Kleinclaus I, Boehm N, Grange $F$, et al. Hereditary progressive mucinous histiocytosis. Ann Dermatol Venereol 2000;127:400-4.

52. Mizushima J, Nogita T, Higaki Y, Kawashima M. Hereditary progressive mucinous histiocytosis. Int J Dermatol 1997;36: 958-60.

53. Sass U, Andre J, Song M. A sporadic case of progressive mucinous histiocytosis. Br J Dermatol 2000;142:133-7.

54. Rongioletti F, Rebora A, Crovato F. Acral persistent papular mucinosis: a new entity. Arch Dermatol 1986;122:1237-9.

55. Chester W. Uber Lipoidogranulomatose. Virchows Arch Pathol Anat 1930;279:561-2.

56. Jaffe $\mathrm{HL}$, editor. Metabolic, degenerative, and inflammatory diseases of bones and joints. Philadelphia: Lea and Febiger; 1972.
57. Veyssier-Belot C, Cacoub P, Caparros-Lefebvre D, Wechsler J, Brun B, Remy $M$, et al. Erdheim-Chester disease: clinical and radiologic characteristics of 59 cases. Medicine (Baltimore) 1996;75:157-69.

58. Murray D, Marshall M, England E, Mander J, Chakera TM. Erdheim-Chester disease. Clin Radiol 2001;56:481-4.

59. Owety T, Scheithauer BW, Ching HS, Lei C, Wong KP. Multiple system Erdheim-Chester disease with massive hypothalamicsellar involvement and hypopituitarism. J Neurosurg 2002;96: 344-51.

60. Wright RA, Hermann RC, Parisi JE. Neurological manifestations of Erdheim-Chester disease. J Neurol Neurosurg Psychiatry 1999;66:72-5

61. Tashjian V, Doppenberg E, Lyders E, Broaddus WC, Pavot $P$, Tye $G$, et al. Diagnosis of Erdheim-Chester disease by using computerized tomography-guided stereotactic biopsy of a caudate lesion. J Neurosurg 2004;101:521-7.

62. Egan AJ, Matthew MBBS, Boardman LA, Tazelaar HD, Swensen SJ, Jett JR, et al. Erdheim-Chester disease: clinical, radiologic, and histopathologic findings in five patients with interstitial lung disease. Am J Surg Pathol 1999;23:17-26.

63. Allen CT, Chevez-Barrios P, Shetlar DJ, Cagle PT. Pulmonary and ophthalmic involvement with Erdheim-Chester disease. Arch Pathol Lab Med 2004;128:1428-31.

64. Krüger S, Kropf C, Wibmer T, Pauls S, Mottaghy FM, Schumann C, et al. Erdheim-Chester disease: a rare cause of interstitial lung disease. Med Klin 2006;101:573-6.

65. Rosai J, Dorfman RF. Sinus histiocytosis with massive lymphadenopathy: a newly recognized benign clinicopathological entity. Arch Pathol 1969;87:63-70.

66. Breuil V, Brocq O, Pellegrino C, Grimaud A, Euller-Ziegler L. Erdheim-Chester disease: typical radiological bone features for a rare xanthogranulomatosis. Ann Rheum Dis 2002;61: 199-200.

67. Feldman EJ. Interferon- $\alpha$ : still useful after all these years. Blood 2005;106:2930-1.

68. Bisceglia M, Cammisa M, Suster S, Colby TV. Erdheim-Chester disease: clinical and pathologic spectrum of four cases from the Arkadi M. Rywlin slide seminars. Adv Anat Pathol 2003; 10:160-71.

69. Devouassoux G, Lalnetuejoul S, Chatelain P, Brambilla E, Brambilla C. Erdheim-Chester disease-a primary macrophage cell disorder. Am J Respir Crit Care Med 1998;157:650-3.

70. Boralevi F, Léauté-Labrèze $C$, Tison F, Bioulac-Sage $P$, Vital $C$, Debrel $X$, et al. Histiocytose langehansienne et maladie d'Erdheim-Chester: une association probablement non fortuite. Ann Dermatol Venereol 1998;125:335-8.

71. Silverstein MN, Ellefson RD, Ahern EJ. The syndrome of the sea-blue histiocyte. N Engl J Med 1970;282:1-4.

72. Kelsey PR, Geary CG. Sea-blue histiocytes and Gaucher cells in bone marrow of patients with chronic myeloid leukemia. J Clin Pathol 1988;41:960-2.

73. Ganguly S, Cunningham MT. Idiopathic thrombocytopenic purpura associated with bone marrow sea-blue histiocytosis. Am J Hematol 2004;77:405-6.

74. Papadaki HA, Michelakaki H, Bux J, Eliopoulos GD. Severe autoimmune neutropenia associated with bone marrow seablue histiocytosis. Br J Haematol 2002;118:931.

75. Howard MR, Kesteven PJL. Sea-blue histiocytosis: a common abnormality of the bone marrow in myelodysplasic syndromes. J Clin Pathol 1993;46:1030-2.

76. Strigaris K, Kokkins K, Liberopoulos K, Kavvadias S, Tsourolas $M$, Nikolacopoulou Z. Liver lesion on computed tomography and ultrasonography in adult Niemann-Pick disease related to sea-blue histiocyte syndrome: a case report. Hepatogastroenterology 1993;40:240-3. 
77. Landa S, Foucar K, Sando GN, Ellefson R, Hamilton HE. Adult Niemann-Pick disease masquerading as sea-blue histiocyte syndrome: report of a case confirmed by lipid analysis and enzyme assay. Am J Hematol 1985;20:391-400.

78. Candoni A, Grimaz S, Doretto P, Fanin R, Falcomer F, Bembi B. Sea-blue histiocytosis secondary to Niemann-Pick disease type B: a case report. Ann Hematol 2001;80:620-2.

79. Bigorgne C, Le Tourneau A, Messing B, Rio B, Giraud V, Molina T, et al. Sea-blue histiocyte syndrome in bone marrow secondary to total parental nutrition including fat-emulsion sources: a clinicopathologic study of seven cases. Br J Haematol 1996; 95:258-62.

80. Rywlin AM, Lopez-Gomez A, Tachmes P, Pardo V. Ceroid histiocytosis of the spleen in hyperlipemias. Am J Clin Pathol 1971;56:572-9.

81. Robinowitz B, Roeknigk HH, Smith MM. Sea-blue histiocytes in mycosis fungoides. Arch Dermatol 1975;111:1165.

82. Allegue F, Soria C, Escribano L, Rocamora A, Moreno R, Ledo A. Sea-blue histiocytes in a patient with mycosis fungoides. Med Cutan Ibero Lat Am 1990;18:141-4.

83. Vacher-Lavenu MC, Baron-Selme V, Abelanet R, Boissonnas L, Laroche C. Le syndrome des histiocytes blues. Revue de litérature à propos d'une observation de splénomégalie idiopatique chez l'adulte. Arch Anat Cytol Path 1983;31:342-50.

84. Quattrin N, De Rosa L, Quattrin S, Cecio A. Sea-blue histiocytosis a clinical, cytologic and nosographic study on 23 cases. Klin Wschr 1978;56:17-30.
85. Zina AM, Bundino S. Familial sea-blue histiocytosis with cutaneous involvement: a case report with ultrastructural findings. Br J Dermatol 1983;108:355-61.

86. Zina AM, Bundino S, Pippione M. Sea-blue histiocyte syndrome with cutaneous involvement case report with ultrastructural findings. Dermatologica 1987;174:39-44.

87. Malinni TI. Unidentified reticuloendothelial cell storage disease. Blood 1961;17:675-86.

88. Pierard GE, Ackerman AB. Histiocytose sea-blue. Bull Soc Lieg Dermatol 1984;8:129.

89. Chainuvati T, Piankijagum A, Viranuvatti V, Silverstein MN. Sea-blue histiocyte syndrome in Thai siblings. Acta Hematol 1977;58:58-64.

90. Boissonnas A, Vacher-Lavenu MC, Foureste V, Forest C, Laroche C, Abelanet R. Le syndrome des histiocytes bleus apparemment idiopathique: une cause rare de splénomégalie chez l'adulte. Nouv Presse Med 1981;10:2294-5.

91. Sawitsky A, Rosner F, Chodsky S. The sea-blue histiocyte syndrome, a review: genetic and biochemical studies. Semin Hematol 1972;9:285-97.

92. Gahr M, Jendrossek V, Peters AMJ, Tegtmeyer F, Heyne K. Sea blue histiocytes in the bone marrow of variant granulomatous disease with residual monocyte NADPH-oxidase activity. $\mathrm{Br} \mathrm{J}$ Haematol 1991;78:278-80.

93. Golde DW, Schneider EL, Bainton DF, Pentchev PG, Brady RO, Epstein $\mathrm{CJ}$, et al. Pathogenesis of one variant of sea-blue histiocytoses. Lab Invest 1975;33:371-8. 